Hơn nữa, niêm mạc trực tràng có nhiêu mao mạch dễ bị tổn thương xây xước khi có quan hệ qua đường này. Có thể tính miễn dịch tế bào tại đường vòng hậu môn thấp hơn so với tính miễn dịch tế bào tại âm đạo, khả năng tự bảo vệ khi có quan hệ tình dục không an toàn thấp.

- Về đặc điểm lâm sàng: Trong 22 bệnh nhân, giang mai 1 có $68,1 \%$ bệnh nhân có săng và $31,8 \%$ bệnh nhân có cả săng và hạch. Trong 126 bệnh nhân giang mai 2 có 74,6\% bệnh nhân chỉ có sẩn, $10,3 \%$ chỉ có đào ban, $14,3 \%$ có cả sẩn và đào ban và có 1 bệnh nhân có đào ban và rụng tóc và không gặp mảng niêm mạc trong giang mai 2.

Săng giang mai thời kỳ 1 vẫn điển hình là vết trợt nông, không đau chiếm tỷ lệ $86,36 \%$ và đáy thương tổn rắn $(95,45 \%)$. Như vậy, các đặc điểm lâm sàng của giang mai thời kỳ 1 và thời kỳ 2 dường như không thay đổi trong những năm gần đây. Chỉ thấy rõ rằng trên những bệnh nhân nhiễm HIV, các tổn thương lâm sàng có sự biến đổi, do đó dễ chẩn đoán nhầm và làm chậm trễ quá trình điều trị, sẽ càng làm phát tán bệnh giang mai ra công đồng và cũng là nguyên nhân gây lây nhiễm HIV. Do đó việc nhận biết các tổn thướng giang mai không điển hình trên người nhiễm HIV là rất quan trọng để phát hiện sớm và có phương pháp điêu trị kịp thời

\section{KẾT LUÂN}

Cho đến nay, bệnh giang mai là một bệnh có tính chất "xã hội" cần được quan tâm. Bệnh có xu hướng gặp nhiều hơn ở đối tượng nguy cơ cao bao gồm nam giới, chưa có gia đình, có quan hêe tình dục không an toàn và quan hệ đồng giới. Đặc biệt, có một tỉ lệ bệnh nhân đồng nhiếm với các bệnh lây truyền qua đường tình dục khác, trong đó có HIV. Do đó, cần tuyên truyền, giáo dục hành vi, nâng cao nhận thức cho các nhóm đối tượng nguy cơ cao.

\section{TÀI LIẸU THAM KHẢO}

1. Nyatsanza F., Tipple C. (2016). Syphilis: presentations in general medicine. Clin Med (Lond), 16(2), 184-188.

2. Peeling R.W., Mabey D., Kamb M.L. et al (2017). Syphilis. Nature Reviews Disease Primers, 3(1), 17073.

3. O'Byrne P., MacPherson P. (2019). Syphilis. Bmj, 365, 1-7.

4. Mao H., Ma W., Lu H. et al (2014). High incidence of HIV and syphilis among migrant men who have sex with men in Beijing, China: a prospective cohort study. BMJ Open, 4(9), 1-10.

5. Baigalmaa J., Erdenechimeg C., Narantuya J. et al (2012). Increasing syphilis notifications in Mongolia: results from national surveillance for 20012011. Western Pac Surveill Response J, 3(4), 86-93.

6. Viện vệ sinh dịch tế Trung Ương (2011), Kết quả giám sát kết hợp hành vi và các chỉ số sinh học HIV/STI (IBBS) vòng II-2009.

\title{
NGHIÊN CỨU ĐĂC ĐIỂM TUỔI, GIỚI VÀ MỐI LIÊN QUAN ĐẾN TỈ LỆ NHIỄM VIRUS DENGUE Ở BỆNH NHÂN NHI
}

\section{TÓM TẮT}

Muc tiêu: Phân tích làm rõ đặc điểm tuổi, giới và mối liển quan đến đến tỉ lệ nhiễm virus dengue ở bệnh nhân nhi. Đối tượng và phương pháp nghiên cứu: 344 bệnh nhân nhi được chẩn đoán sốt xuất huyết Dengue giai đoạn cấp tính trong vòng 3 ngày của sốt, được nhập viện điêu trị tại khoa nhi bệnh viện Nhi Đồng 1 , bệnh viện Tiền Giang và bệnh viện Nhi Đồng Đồng Nai từ tháng 1-2011 đến tháng 122015.Tất cả các bênh nhân đều được thân nhân và người nhà đồng ýy tham gia nghiên cứu. Tiến hành thu thập thônng tin tuổi giới, huyết thanh của bệnh nhân, tách RNA. Sử dụng phản ứng Multiplex RT-PCR xác

${ }^{1}$ Bệnh viện Quân y 103

${ }^{2}$ Hoc viên Quân y

Chịu trách nhiệm chính: Đặng Thành Chung

Email: dangthanhchung@vmmu.edu.vn

Ngày nhận bài: 10.3.2021

Ngày phản biên khoa học: 10.5.2021

Ngày duyệt băi: 17.5.2021

\section{Nguyễn Đức Thuận ${ }^{1}$, Đặng Thành Chung ${ }^{2}$}

định các type huyết thanh của virữ DENV. Kết quả: Bệnh nhân ở các khoảng tuổi nhiếm cả 4 type virus: type 1 (DENV-1), type 2 (DENV-2), type 3 (DENV-3) và type 4 (DENV-4). Trong đó khoảng khoảng tuổi 6 10 chiếm tỉ lệ cao nhất $(50,43 \%-63,24 \%)$, sau đó là khoảng tuổi $11-15(23,53 \%$ - 38,46\%), và thấp nhất là khoảng tuổi $\leq 5(11,11 \%-15,79 \%)$ ở cả 4 type virus, tuy nhiên không có sự khác biệt về tuổi giữa các type virus, với $p=0,1338$. Tỉ lệ nhiễm virus của hại giới là tương đương nhau ở các type virus 1,2 và 4 . Ơ type 3 tỉ lệ ở nữ $(63,16 \%)$ cao hơn ở nam $(36,84 \%)$, tuy nhiên sự khác biệt giữa hai giới không có ý nghĩa thống kê với $p=0,2513$. Kết luận: Không có sự khác biệt về tuổi và giới giữa các trường hợp nhiếm các type virus khác nhau, tuy nhiên ở độ tuổi 6-10 nhiễm virus chiếm tỉ lệ cao nhất ở cả 4 type, tỉ lệ nhiễm type 3 ở nữ cao hơn ở nam.

Tư khóa: tuổi, giới, virus denge, type huyết thanh, nhi.

\section{SUMMARY}

STUDY ON AGE, GENDER 


\section{CHARACTERISTICS, AND RELATION TO DENGUE VIRUS INFECTION INCIDENCE IN PEDIATRIC PATIENTS}

Objectives: Analyze age, gender characteristics, and association with dengue virus prevalence in pediatric patients. Subjects and methods: 344 pediatric patients diagnosed with febrile dengue phase within three days of fever, admitted to the Department of Pediatrics at Children Hospital No.1 in Ho Chi Minh City, Tien Giang General Hospital and Dong Nai Children Hospital from January 2011 to December 2015, Participation in the study was voluntary and agreed to participate in the study by their relatives and family members. Proceeding to collect information about the patient's age, gender, serum, and RNA extraction, using Multiplex RT-PCR reaction to determine the serotypes of Dengue virus. Results: Patients of all ages range infected with all four serotype viruses: type 1 (DENV-1), type 2 (DENV-2), type 3 (DENV-3), and type 4 (DENV-4). Of which, the age range $6-10$ accounts for the highest percentage $(50.43 \%-63.24 \%)$, followed by the age range $11-15(23.53 \%-38.46 \%)$, and the lowest is about age $\leq 5(11.11 \%-15.79 \%)$ for all four virus serotypes, however, there is no age difference between the virus serotypes, with $p=0.1338$. The rates of viral infections of the two sexes were similar for types 1,2 , and 4 . In type 3, the girls $(63.16 \%)$ was higher than in boys (36.84\%), but the difference was not statistically significant with $\mathrm{p}=$ 0.2513 . Conclusion: There is no difference in age and gender of viral serotype infections. However, at the age of $6-10$, viral infection accounts for the highest rate in all four types, the incidence of type 3 infection in girls higher in boys.

Key words: age, gender, dengue virus, serotypes, pediatric.

\section{I. ĐĂT VẤN ĐỀ}

Sốt xuất hyết là môtt bênh truyền nhiễm ở các nước nhiệt đới và cận nhiệt đới có thể gây bệnh nặng và tử vong. Trong 30 năm qua, bệnh sốt xuất huyết đã mở rộng đáng kể phạm vi địa lý và rút ngắn chu kỳ dich ở nhiêu nời. Theo Tồ chức Y tế Thế giới (WHO), bệnh sốt xuất huyễt lưu hành ở hơn 100 quốc gia và khoảng hai phần năm dân số thễ giới hiện có nguy cơ mắc bệnh sốt xuất huyết với ước tính khoảng 50 triệu ca nhiễm hàng năm [1]. Trong số ước tính 2,5 tỷ người có nguy cơ mắc bệnh sốt xuất huyết trên toàn câu, có khoảng 1,8 tỳ người (tức hơn $70 \%$ ), sống ở các nước Châu Á Thái Bình Dương [2]. Vật trung gian truyền bệnh sốt xuất huyễt quan trọng nhất, Aedes aegypti, là loài muỗi chủ yễu sống ở đô thi ưa thích các môi trường chứa nước và khu xử lý chất thải không tuân thủ đúng qui trình [3]. Mặc dù việc tiếp xúc với những môi trường như vậy có thể liên quan đến các yếu tố nhân khẩu học cụ thể như tuổi tác và giới tính, nhưng có rất về dữ liệu sốt xuất huyễt liên quan đễn tuổi và giới tính.

Thật vậy, dữ liệu về sốt xuất huyết phân tách theo giới tính không được hệ thống giám sát báo cáo hoặc phân tích thường xuyên. Một số ít nghiên cứu từ Châu Á, chẳng hạn như các nghiên cứu từ Singapore, đã kiểm tra tỷ lệ mắc bệnh sốt xuất huyết ở nam và nữ, có xu hướng tìm thấy tỷ lệ mắc bệnh ở nam giới cao hơn [4]. Sự khác biêt về tỷ lệ mắc bênh sốt xuất huyết theo giới tính được cho là liên quan đến thời gian xa nhà phơi nhiễm [4]. Khi nói đến mức độ nghiêm trong của bênh, môt yếu tố nguy cơ dich tể được xác định rõ ràng là tuổi mắc bệnh [5]. Được biết, sự khác biệt về bệnh sốt xuất huyết biểu hiện lâm sàng thay đổi theo độ tuổi; trẻ em trước tuổi đi học và trẻ sơ sinh thường sốt không rõ ràng trong khi trẻ em trước tuổi vị thành niên thường có sốt, hơn nữa trẻ nhỏ bị sốt xuất huyết Dengue có biểu hiện lâm sàng nghiêm trọng hơn (ví dụ tỳ lệ tử vong trong trường hợp cao hơn) hơn người lớn [6].

Tại việt nam đánh giá đặc điểm tuổi, giới và mối liên quan với tî lệ nhiễm virus dengue ở bênh nhân nhi còn chưa được đánh giá một cách cụ thể, vì thế nghiên của của chúng tôi tập trung làm rõ vẫn đề này

\section{II. ĐỐI TƯỢNG VÀ PHƯƠ'NG PHÁP NGHIÊN CỨU}

2.1 Đối tượng nghiên cứu: 344 bệnh nhân nhi được chẩn đoán sốt xuất huyết Dengue giai đoạn cấp tính trong vòng 3 ngày của sốt, được nhập viện điều trị tại khoa nhi bệnh viện Nhi Đồng 1 , bệnh viện Tiền Giang và bệnh viện Nhi Đồng Đồng Nai từ tháng 1-2011 đển tháng 122015.Tất cả các bệnh nhân đều được thân nhân và người nhà đồng ý tham gia nghiên cứu.

2.2 Phương pháp nghiên cứu: Thông tin tuổi, giới được thu thập. Mẫu máu của các bệnh nhân được bảo quản lạnh và chuyển tới trung tâm xét nghiệm của bệnh viện để tách huyễt thanh bằng máy li tâm lạnh. Tất cả các mẫu được bảo quản trong đông sâu $-80^{\circ} \mathrm{C}$ cho đến khi tiến hành tách RNA. Mẫu huyết thanh của bệnh nhân được tiến hành tách RNA sử dụng kit tách chiết RNA từ virus của Hàn Quốc "GeneAll ExgeneTM Viral DNA/RNA" (GeneAll, 128-150). Quy trình tách được thực hiện theo hướng dẫn của nhà sản xuất.

Lựa chọn mồi (primers) để xác định các type virus của virus DENV: Các bộ mồi khác nhau để xác định type virus của virus DENV được tìm kiếm dựa trên các nghiên cứu trước đó theo tiêu chí để đảm bảo đặc hiệu, độ nhạy, khả năng tương thích, khác nhau về kích thước sản phẩm 
PCR (amplicon), thành phân guanine-cytosine, kích cỡ mồi và nhiệt độ biến tính. Trong nghiên cứu này chúng tôi lựa chọn bộ mồi để định type virus của virus DENV dựa trên nghiên cứu của Lanciotti và cộng sự[7]. Được tóm tắt theo bảng sau:

\begin{tabular}{|c|c|c|c|}
\hline $\begin{array}{l}\text { Type } \\
\text { virus }\end{array}$ & Mồi & Trình tự môi & $\begin{array}{c}\text { Kích thước sản phấm } \\
\text { PCR }\end{array}$ \\
\hline & Dcon & 5'-TCAATATGCTGAAACGCGCGAGAAACCG-3' & \\
\hline DENV-1 & $\mathrm{D} 1$ & $5^{\prime}$-CGTCTCAGTGATCCGGGGG-3' & 482 bp (Dcon\&D1) \\
\hline DENV-2 & D2 & 5'-CGCCACAAGGGCCATGAACAG-3' & 119 bp (Dcon\&D2) \\
\hline DENV-3 & D3 & 5'-TAACATCATCATGAGACAGAGC-3' & 290 bp (Dcon\&D3) \\
\hline DENV-4 & D4 & 5'-CTCTGTTGTCTTAAACAAGAGA-3' & 392 bp (Dcon\&D4) \\
\hline
\end{tabular}

Dcon: dengue conserved region.

Phản ứng Multiplex RT-PCR xác định các type virus của virus DENV: $5 \mu \mathrm{L}$ của RNA tách từ huyết thanh của bệnh nhân được khuếch đại trong $50 \mu \mathrm{L}$ hỗn hợp phản ứng với $0.5 \mathrm{mM}$ mồi upstream Dcon và bốn mồi downstream đặc hiệu cho type virus của virus DENV (D1-D4) sử dụng OneTaq One-step RT-PCR Kit (NEB, E5315S), là kit kết hợp 2 bước tạo CDNA và khuếch đại PCR trong cùng một phản ứng, qui trình tuân theo hướng dẫn của nhà sản xuất. Ống PCR được li tâm ngắn, phản ứng phiên mã ngược được thực hiện với một chu kỳ tại $50^{\circ} \mathrm{C}$ trong 30 phút, sau đó phản ứng khuếch đại PCR với 35 chu kỳ theo chu trình nhiệt như sau $\left(95^{\circ} \mathrm{C}\right.$ trong 30 giây, $55^{\circ} \mathrm{C}$ trong 45 giây và $72^{\circ} \mathrm{C}$ trong 2 phút). Kích thước của sản phẩm PCR thu được sẽ đăc hiêuu cho từng type virus khác nhau của virus DENV, ví dụ 482 bp cho DENV-1; 119 bp cho DENV-2; 290 bp cho DENV-3 và 392 bp cho DENV-4. Được xác định thông qua điện di sử dụng gel Agarose $2 \%$ và hệ thống đọc gel kỹ thuật số (Alpha Innotech, San Leandro, CA).

Các số liệu thu thập được xử lí theo thuât toán thống kê bằng chương trình phân mềm Exel và và GraphPad Prism với các phương pháp: Các dữ liệu dạng đề mục được trình bày dưới dạng con số và tỷ lệ phần trăm. Đối với số liêuu tuân theo phân phối chuẩn sử dung phương pháp thống kê Kruskal-Wallis và chi-squared (X2), với $\mathrm{p} \leq 0,05$ được coi là có ý nghĩa thống kê.

\section{KẾT QUẢ NGHIÊN CỨU}

Bảng 1. Phân bố về tuổi và nhóm tuổi của bệnh nhân theo type virus

\begin{tabular}{|c|c|c|c|c|c|c|c|}
\hline & & $\begin{array}{l}\text { DENV-1 } \\
\text { Số (\%) }\end{array}$ & $\begin{array}{l}\text { DENV-2 } \\
\text { Số (\%) }\end{array}$ & $\begin{array}{l}\text { DENV-3 } \\
\text { Số (\%) }\end{array}$ & $\begin{array}{l}\text { DENV-4 } \\
\text { Số (\%) }\end{array}$ & $\begin{array}{c}\text { Tống số } \\
(\%)\end{array}$ & $\mathbf{P}$ \\
\hline \multicolumn{2}{|c|}{ Khoảng tuối (năm) } & $3-15$ & $1-14$ & 4-13 & $3-15$ & $1-15$ & \multirow{5}{*}{0,1338} \\
\hline \multirow{3}{*}{$\begin{array}{l}\text { Tuổi } \\
\text { bệnh } \\
\text { nhân }\end{array}$} & $\leq 5$ & $13(11,11)$ & $9(13,24)$ & $3(15,79)$ & $14(10,00)$ & $39(11,34)$ & \\
\hline & $6-10$ & $59(50,43)$ & $43(63,24)$ & $10(52,63)$ & $77(55,00)$ & $189(54,94)$ & \\
\hline & $11-15$ & $45(38,46)$ & $16(23,53)$ & $6(31,58)$ & $49(35,00)$ & $116(33,72)$ & \\
\hline \multicolumn{2}{|c|}{ Trung vị } & 10 & 8 & 9 & 10 & 9 & \\
\hline
\end{tabular}

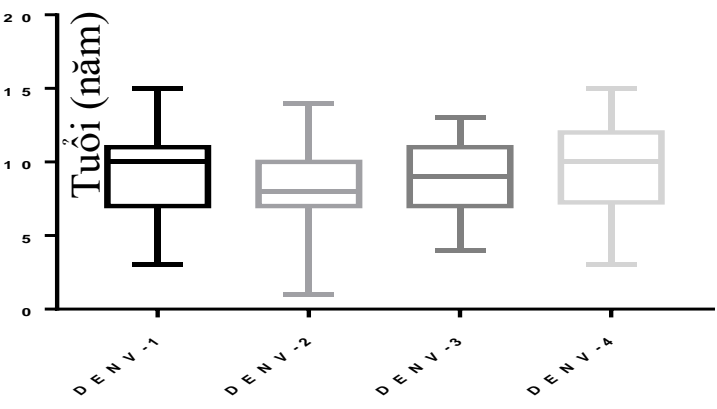

Hình 1. Đồ thị biểu diễn phân bố tuổi theo type virus của bệnh nhân

Nhận xét: Kết quả cho thấy không có sự khác biệt về tuổi giữa các type virus, với $p=$ 0,1338, sử dụng phương pháp thống kê "Kruskal-Wallis test".

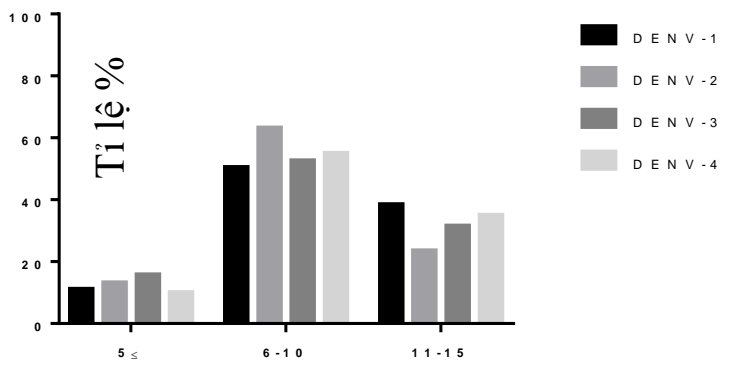

Hình 2. Đồ thị biểu diễn phân bố nhóm tuổi theo type virus của bệnh nhân, với 3 nhóm tuổi $\leq$ 5; 6-10 và 11-15 tuổi.

Nhân xét: Qua đồ thi cho thấy ở độ tuổi 610 nhiểm virus Dengue chiếm tỉ lệ cao nhất, và thấp nhất ở độ tuổi $\leq 5$ ở tất cả các type virus của virus Dengue. 
Bảng 2. Phân bố về giới theo type virus của virus Dengue

\begin{tabular}{|c|c|c|c|c|c|}
\hline & $\begin{array}{c}\text { DENV-1 } \\
\text { Số (\%) }\end{array}$ & $\begin{array}{c}\text { DENV-2 } \\
\text { Số (\%) }\end{array}$ & $\begin{array}{c}\text { DENV-3 } \\
\text { Số (\%) }\end{array}$ & $\begin{array}{c}\text { DENV-4 } \\
\text { Số (\%) }\end{array}$ & $\begin{array}{c}\text { Tống Số } \\
\text { (\%) }\end{array}$ \\
\hline Nam & $57(48,72)$ & $38(55,88)$ & $7(36,84)$ & $71(50,71)$ & $173(50,29)$ \\
\hline Nữ & $60(51,28)$ & $30(44,12)$ & $12(63,16)$ & $69(49,29)$ & $171(49,71)$ \\
\hline P & 0,781511 & 0,33 & 0,251349 & 0,87 & 0,914128 \\
\hline
\end{tabular}

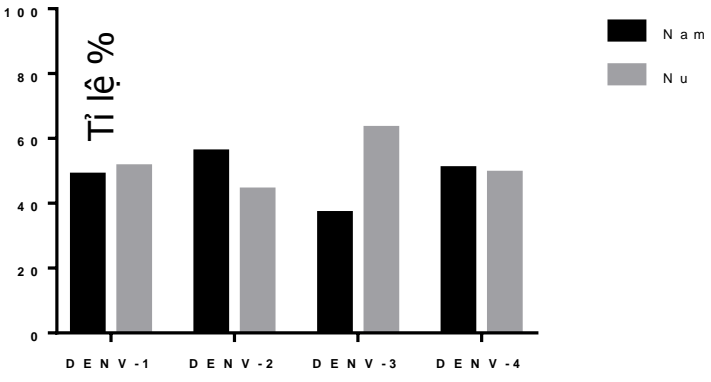

Hình 3. Đồ thị biểu diễn tỉ lệ về giới theo type virus

Nhận xét: Kết quả cho thây tỉ lệ nhiễm virus của hai giới là tương đương nhau ở các type virus 1,2 và 4 . Ở type 3 tỉ lệ ở nữ $(63,16 \%)$ cao hơn ở nam (36,84\%). Tuy nhiên sự khác biệt giữa hai giới không có ý nghĩa thống kê ở tất cả các type huyết thanh, sử dụng phương pháp thống kê "Chi-square".

\section{BÀN LUÂN}

Trong khảo sát của chúng tôi trên 344 bệnh nhân cho thấy khoảng tuổi của đối tượng bị nhiễm là tương tự nhau ở các type virus. Kết quả cũng tương đồng với nghiên cứu Halsey và cộng sự khảo sát ở đối tượng $\leq 10$ tuổi [8]. Tuy nhiên khi chia nhỏ các đổi tượng thành các 3 nhóm tuổi ( $\leq 5 ; 6-10$ và $11-15$ tuổi), kết quả cho thây ở độ tuổi 6-10 nhiễm virus Dengue chiếm tỉ lệ cao nhất (54,94\%), và thấp nhất ở độ tuổi $\leq 5$ $(11,34 \%)$. Kết quả này tương tự với nghiên cứu của Balmaseda và cộng sự khi khảo sát trên đối tượng trẻ từ 0-14 tuổi, với trẻ ở độ tuổi 5-9 có tỉ lệ nhiễm virus cao nhất, trong khi nhóm tuổi 0-4 tuổi chiếm tỉ lệ thấp nhất. Như vậy nhóm trẻ nhỏ ở độ tuổi 6-10 có nguy cơ cao nhất bị lây nhiễm Dengue, tuy nhiên lý do vì sao nhóm tuổi này lại có nguy cơ cao hơn các nhóm tuổi khác thì cho đến nay vẫn chưa có nghiên cứu nào chỉ ra được nguyên nhân hay cơ chế, có thể giả thuyết là nhóm tuổi này đã bắt đầu đến độ tuổi đến trường làm tăng cơ hội cho vector truyền bệnh, đồng thời ở độ tuổi này chưa có kháng thể kháng lại virus Dengue, nhóm trẻ nhỏ hơn có thể do còn một lượng nhất định kháng thể kháng virus từ me truyền qua nhau thai, và nhóm trẻ lớn hơn thì có nhiều khả năng đã có kháng thể kháng virus Dengue ở lần nhiễm ở độ tuổi nhỏ hơn vì thế tỉ lệ nhiễm sẽ thấp hơn nhóm 6-10 tuổi, tuy nhiên những lý giải đó hoàn toàn vẫn là giả thuyết và cần có những nghiên cứu cụ thể để chứng minh điều đó. Cũng trong nghiên cứu của Halsey ở đối tượng người trưởng thành nhóm tuổi 21-30 có tỉ lệ nhiễm virus Dengue là cao nhất $27,2 \%$ và nhóm $>60$ tỉ lê nhiếm là thấp nhất $3,1 \%$, trong khi tỉ lệ nhiếm với các type virus ở cùng nhóm tuổi là tương đương nhau [8].

Khi khảo sát đặc điểm phân bố về giới ở các type virus, kết quả cho thấy tỉ lệ nhiễm DENV-1; DENV-2, DENV-4 là tương đương ở hai giới; với DENV-3, nữ giới chiếm tới $63,16 \%$ cao hơn so với nam giới chiếm 36,84 \% tuy nhiên sự khác biệt chưa có ý nghĩa thống kê, có lẽ là do số lượng nhiễm DENV-3 trong nghiên cứu của chúng tôi còn thấp (19/344). Trong nghiên cứu của Halsey và cộng sự trên 1716 ca nhiễm virus Dengue, kêt quả cho thây tỉ lệ nhiễm giữa hai giới là tương đương, tuy nhiên ở DENV-2 nam chiếm $63,5 \%$ cao hơn so với nữ giới chiếm 36,5 $\%$, trong khi các type còn lại nữ giới có tỉ lệ cao hơn không đáng kể so với nam giới [8]. Trong một nghiên cứu khác của Tsai và cộng sự tỉ lệ nhiễm virus ở nữ (54.3\%) cao hơn không đáng kể so với nam giới $(45,7 \%)$, khi khảo sát theo type virus DENV-2 và DENV-3 ở nữ vẫn có tỉ lệ cao hơn nhưng không đáng kể. Trong một nghiên cứu khác của Yung và cộng sự nghiên cứu trên đối tượng người trưởng thành từ năm 2005-2011, cho thấy tỉ lệ nhiễm DENV-1, DENV2 và DENV-3 ở nam cao hơn có ý nghĩa thống kê so với nữ giới. Như vậy ảnh hưởng của yếu tố giới tính lên khả năng nhiễm virus Dengue ở các type khác nhau vẫn còn chưa rõ và khá khác nhau tùy thuộc vào từng nghiên cứu riêng rẽ. Trong nghiên cứu này của chúng tôi tỉ lệ nhiễm DENV-3 ở nữ giới là cao hơn ở nam mặc dù chưa có ý nghĩa thống kê, điều này cần phải được xác minh ở cõ mẫu lớn hơn.

\section{KẾT LUÂ̂N}

Không có sự khác biệt về tuổi và giới giữa các trường hợp nhiễm các type virus khác nhau, tuy nhiên ở độ tuổi 6-10 nhiếm virus chiếm tỉ lệ cao nhất ở cả 4 type, tỉ lệ nhiễm type 3 ở nữ cao hơn ở nam. 
Bệnh nhân ở các khoảng tuổi nhiễm cả 4 type virus: type 1 (DENV-1), type 2 (DENV-2), type 3 (DENV-3) và type 4 (DENV-4). Trong đó khoảng khoảng tuổi 6-10 chiếm tỉ lệ cao nhất (50,43\% $63,24 \%)$, sau đó là khoảng tuổi 11-15 (23,53\% $38,46 \%)$, và thấp nhất là khoảng tuối $\leq 5$ $(11,11 \%-15,79 \%)$ ở cả 4 type virus, tuy nhiên không có sự khác biệt về tuổi giữa các type virus, với $p=0,1338$. Tỉ lệ nhiễm virus của hai giới là tương đương nhau ở các type virus 1,2 và 4. Ở type 3 tỉ lệ ở nữ $(63,16 \%)$ cao hơn ở nam $(36,84 \%)$, tuy nhiên sự khác biệt giữa hai giới không có ý nghĩa thống kê với $p=0,2513$

\section{TÀI LIỆ THAM KHẢO}

1. Geneva, W.H.O. Fact sheet $\mathbf{N}^{\circ} \mathbf{1 1 7}$, Dengue and dengue hemorrhagic fever, March 2009; Available from: http://www.who.int/ mediacentre/factsheets/fs117/en/, accessed 26 December 2010.
2. Manila, W.H.O.W.P.R.O. Dengue in the Western Pacific. 2010; Available from: http:// www.wpro.who.int/ topics/ dengue/en, accessed 20 December 2010.

3. Huy, R., et al., National dengue surveillance in Cambodia 1980-2008: epidemiological and virological trends and the impact of vector control. Bulletin of the World Health Organization, 2010. 88(9): p. $650-657$.

4. Ooi, E.E., Changing Pattern of Dengue Transmission in Singapore. 2001.

5. Yew, Y.W., et al., Seroepidemiology of dengue virus infection among adults in Singapore. Ann Acad Med Singap, 2009. 38(8): p. 667-75.

6. Guzmán, M.G., et al., Effect of age on outcome of secondary dengue 2 infections. Int J Infect Dis, 2002. 6(2): p. 118-24.

7. Lanciotti R. S., et al., Rapid detection and typing of dengue viruses from clinical samples by using reverse transcriptase-polymerase chain reaction. $]$ Clin Microbiol, 1992. 30(3): p. 545-51.

8. Halsey E. S., et al., Correlation of serotype-specific dengue virus infection with clinical manifestations. PLoS Negl Trop Dis, 2012. 6(5): p. e1638.

\section{KIẾN THỨC, THÁI ĐỘ VỀ SÀNG LỌC UNG THƯ ĐẠI TRỰC TRÀNG CỦA NGƯỜI DÂN TỪ 50-75 TUỔI TRÊN ĐİA BÀN QUÂ̂N HOÀN KIẾM, HÀ NộI NĂM 2019}

\section{TÓM TẮT}

Muc tiêu: Mô tả kiến thức, thái đô và nhân thức về rào cản đối với việc chi trả tiền túi để thực hiện sàng loc ung thư đai trực tràng của người dân từ 5075 tuổi trên địa bàn quận Hoàn Kiếm, Hà Nội năm 2019.Phương pháp: Điều tra cắt ngang trên 402 đối tượng 50-75 tuổi đển khám bệnh thông thường tại các phòng khám ngoại trú thuộc Trung tâm y tế quận Hoàn Kiếm từ tháng 1 đến tháng 3/2019. Kết quả và kết luâan: Kiến thức và thái độ ("không nghĩ mình có bệnh" hay "thiếu hiểu biết thông tin khám sàng lọc", "không biết về phương pháp này có thể sàng lọc được" hay "chỉ khi nào có biểu hiện bệnh thì mới đi khám") là yếu tố phổ biến nhất $(43,7 \%)$ mà đối tượng đưa ra trong số các rào cản được đối tượng chỉ ra trong việc chi trả tiền túi để thực hiện xét nghiệm FOBT. Rào cản phổ biến nhất đối với chi trả tiên túi đối với nội soi đại trực tràng liên quan đến sự "sợ hãi khi phát hiện ra bệnh", "sợ đến bệnh viện", "sợ gây mê", "sỡ đưa dụng cụ vào cơ thể gây khó chịu" hay "sợ đau" (34,8\%).

Từ khóa: kiến thức, thái độ, rào cản, sàng lọc ung thư đại trực tràng, nội soi đại trực tràng, FOBT

*Trường Đại học Y tế Công cộng

Chịu trách nhiệm chính: Nguyễn Quỳnh Anh

Email: nqa@huph.edu.vn

Ngày nhận bài: 11.3.2021

Ngày phản biên khoa hoc: 11.5.2021

Ngày duyệt bài: 17.5.2021
Nguyễn Quỳnh Anh*, Nguyễn Thu Hà*

\section{SUMMARY \\ KNOWLEDGE AND ATTITUDES RELATED TO COLORECTAL CANCER SCREENING OF PEOPLE AGED 50-75 YEARS IN HOAN KIEM} DISTRICT, HANOI, 2019

Objective: To describe knowledge, attitudes and perceptions about barriers to colorectal cancer screening of people aged 50-75 years in Hoan Kiem district, Hanoi, 2019.Method: Cross-sectional survey conducted on 402 patients aged $50-75$ years old who went to the outpatient clinics of Hoan Kiem District Medical Center from January to March 2019. Results and conclusion: Knowledge and attitudes ("don't think I have cancer" or "lack of information of screening ", "don't know about the screening techniques " or "only seek treatment when there is a sign of cancer) ") is the most common factor (43.7\%) among the perceived barriers to out of pocket payment to FOBT. The most commom barrier to pay for colonoscopy involve "fear of finding out the disease", "fear of going to the hospital", "fear of anesthesia", "giving the device into the body causing discomfort" or "fear of pain" (34.8\%).

Keywords: knowledge, attitude, percieved barriers, colonoscopy, colorectal cancer screening

\section{I. ĐĂT VẤN ĐỀ}

Tai Viêt Nam, ung thư đai trức tràng (UTĐTT) cùng với các nhóm ung thư khác là một trong 